\title{
Liryka pokwitania i uroki filmoznawczej pasji
}

\author{
Kostyra, K. (2019). Wiosenna bujność traw. Obrazy przyrody \\ w filmach o dorastaniu. Wydawnictwo UŚ.
}

\begin{abstract}
Abstrakt:
W artykule recenzyjnym omówiono książkę Karoliny Kostyry zatytułowaną Wiosenna bujność traw. Obrazy przyrody w filmach o dorastaniu (2019). Rozprawa dotyczy filmów coming of age. Autorka tekstu wskazuje na miejsce tej monografii w teorii gatunku, w tendencjach pojawiających się we współczesnej humanistyce, a także w dyskursie akademickim, którego alternatywną formułę określa za Laurą U. Marks jako krytykę haptyczną (ten termin zostaje użyty w opisie stylu Kostyry).

Słowa kluczowe:

dorastanie, filmy o dorastaniu, ideologia, Karolina Kostyra, krytyka haptyczna, teoria gatunków filmowych
\end{abstract}

The Poetry of Pubescence and the Charm of a Film Scholar's Passion

Kostyra, K. (2019). Wiosenna bujność traw. Obrazy przyrody w filmach

o dorastaniu. Wydawnictwo UŚ.

\section{Abstract:}

The review article discusses Karolina Kostyra's book Wiosenna bujność traw. Obrazy przyrody w filmach o dorastaniu [Splendor in the Grass: Nature Images in Coming-of-Age Films] (2019). The author of the paper emphasises the place of the monograph in the contexts of the film genre theory, new humanities' tendencies,

* Marta Stańczyk - dr, pracuje w Instytucie Sztuk Audiowizualnych na Wydziale Zarządzania i Komunikacji Społecznej Uniwersytetu Jagiellońskiego w Krakowie. Jej zainteresowania obejmują cielesne teorie filmu, przemiany kina współczesnego, wątki feministyczne w kulturze popularnej oraz ekranową obecność zwierząt. Kontakt: martal.stanczyk@uj.edu.pl. 
and the academic discourse. The alternative for the last issue is the so-called haptic criticism, term coined by Laura U. Marks and used by the article's author to describe Kostyra's style.

\section{Key words:}

coming of age, coming-of-age films, ideology, Karolina Kostyra, haptic criticism, film genre theory

$\mathcal{G}$ host World Daniela Clowesa (1997) i adaptacja tego komiksu w reżyserii Terry'ego Zwigoffa (2001) próbują uchwycić ten rozedrgany moment „pomiędzy” - gdy już nie jesteśmy dziećmi, nie chcemy być dorosłymi, gardzimy jednymi i drugimi, ale nie potrafimy zmieścić się we własnej skórze i społecznych oczekiwaniach. Oba dzieła pokazują dojrzewanie jako naukę kompromisów. Bohaterki, Enid i Rebecca (w filmie grane przez Thorę Birch i Scarlett Johansson), konfrontują się z kolejnymi pozornymi rytuałami przejścia, te ostatnie jednak nie cechują się sensualną i tożsamościową doniosłością. Okazuje się, że młodość to wiek rozczarowań, do którego nie ma nostalgicznego powrotu - nostalgia jest jedną z masek, sentymentalizującą wiek upokorzeń, niepewności i rozczarowań.

Piszę o Ghost World z kilku względów. Po pierwsze, tak komiks, jak i film pokazują dorastanie jako ciągłe przymierzanie tożsamości w poszukiwaniu tej skrojonej na własną miarę. Po drugie, samoświadomość bohaterek przekłada się na autorefleksyjność wspomnianych tekstów, pokazujących klisze, z których „uszyty” zostaje schemat narracji o dorastaniu - coming of age. Po trzecie, Ghost World jest dla mnie przykładem dzieła o niedopasowaniu jako głównym doświadczeniu okresu dojrzewania - monografię gatunku, którą napisała Karolina Kostyra (2019), ja stworzyłabym nie wokół tęsknoty, a uczucia ulgi, stając obok tych wszystkich chłopców z nadwagą z filmów o dojrzewaniu, o których wspomina autorka, obok zakompleksionej Kayli (Elsie Fisher) z Ósmej klasy Bo Burnhama (2018) czy nieśmiałej Emily (Taylor Russell) z Fal Treya Edwarda Shultsa (2019).

Oczywiście selekcja filmów i wątków jest dobrą, a wręcz potrzebną praktyką w każdej monografii, zwłaszcza że - jak autorka słusznie wskazuje - na gruncie polskim nie powstała dotychczas żadna tego typu publikacja o kinie coming of age, a i za granicą Kostyra (2019, s. 7-8) odnajduje jedynie cztery rozprawy książkowe na ten temat, choć albo o zawężonej perspektywie, albo o encyklopedycznym charakterze. Wspominam jednak o możliwym innym ujęciu, ponieważ uświadamia ono zawężenie zakresu pola badawczego. Wiosenna bujność traw (która znalazła się w finale organizowanego przez Polskie 
Towarzystwo Badań nad Filmem i Mediami konkursu na najlepszy filmoznawczy i medioznawczy debiut roku 2019) za cel stawia sobie scharakteryzowanie gatunku coming of age oraz uchwycenie fenomenu młodości - obie kategorie łączone są zaś z przyrodą. Badaczka kreśli tę problematykę we wprowadzeniu, w „części szkolnej” (s. 19), wskazując na stan badań, charakteryzując wstępnie gatunek, przedstawiając narzędzia metodologiczne i sposób selekcji. Część główna książki, podobnie jak (zwykle) dwumiesięczne wakacje, składa się z dwóch rozdziałów: Szałasy oraz Letniska. W pierwszym z nich Kostyra opisuje cztery filmy - Stań przy mnie Roba Reinera (1986), Królowie lata Jordana Vogta-Robertsa (2013), Walkabout Nicholasa Roega (1971) i Płyna tratwy Władysława Ślesickiego (1962); w drugim jest to pięć tytułów - Zapamiętajmy to lato Siergieja Sołowjowa (1975), Wycieczka na wieś Jeana Renoira (1946), Dancing w kwaterze Hitlera Jana Batorego (1972), Zepsuty owoc Kô Nakahiry (1956) i Nad rzeką, której nie ma Andrzeja Barańskiego (1991). Rozprawę wieńczy podsumowanie, zatytułowane tak samo jak cała monografia.

W części głównej autorka analizuje zatem dziewięć filmów: „Dziewięć to - jak pisze - liczba dobra jak każda inna, ale taki wybór pozwala ukazać filmy coming of age w ich szerszym zakresie, obejmując osiemdziesiąt lat historii kina i sześć kinematografii narodowych" (Kostyra, 2019, s. 17). Ta uwaga wskazuje już na dwie główne cechy, które czasami odsłaniają pewne słabości hermeneutyczne wywodu: selekcja materiału badawczego w niektórych partiach książki uderza arbitralnością, a esencjalizm i partykularność wchodzą ze sobą w konflikt. Z jednej strony autorka traktuje bowiem film Reinera jako współczesną matrycę skonwencjonalizowanych narracji o dojrzewaniu, a w dalszej części książki dobiera nieoczywiste przykłady, zwłaszcza z kina polskiego, ale także interpretuje chociażby Wycieczkę na wieś Renoira jako film coming of age. $\mathrm{Z}$ drugiej zaś strony brak uporządkowanej refleksji na temat gatunku i jego reprezentantów uniemożliwia nakreślenie szerszej perspektywy wertykalnej i horyzontalnej. Wybrane egzemplifikacje kina coming of age wydają się przypadkowym i w znacznej mierze ahistorycznym zbiorem, zwłaszcza że poszczególne konteksty kulturowo-filmowe są pobieżnie nakreślone. W podrozdziale o Stań przy mnie nie zostało uwzględnione znaczenie kina lat 50. XX wieku, którą to dekadę idealizowała reaganomatografia ${ }^{47}$ w latach 80. (Syska 2012),

1 „Te [ideologiczne przemiany] nadeszły dopiero na początku lat 80., gdy w Białym Domu zasiadł znany z konserwatywnych poglądów zaciekły antykomunista i gospodarczy liberał, Ronald Reagan. Na charakterze jego poglądów zaważyła potrzeba powrotu do tradycyjnych wartości Środkowego Zachodu - z nobilitacją rodziny (zamiast komun hipisowskich), z kontrofensywą religii chrześcijańskiej (zamiast ruchów wyrosłych z New Age’u), 
a choć inne konteksty związane z Ameryką są rozległe (mit ziemi i otwartej przestrzeni, amerykańscy romantycy itd.), to chociażby kontekst kina australijskiego jest bardzo powierzchownie ujęty i uzupełniony nieprzekonująco zaaplikowanym wątkiem kina kontestacji i flower power (Kostyra, 2019, s. 61-63).

„Filmy szałasowe” z pierwszego rozdziału Kostyra umieszcza w kontekście scenariusza rytualnego, któremu patronują antropologiczne prace Arnolda van Gennepa (1909/2006) i Mircei Eliadego (1959/1997). Opisuje obrzędy inicjacyjne i przestrzenie liminalne, by zaprezentować proces dojrzewania jako moment transformacji, ucieleśniający mit regressus ad uterum - głoszący, że koniec i początek, śmierć i narodziny sąsiadują ze sobą nierozerwalnie. Z kolei „filmy letniskowe”, analizowane w drugim rozdziale, to przede wszystkim case studies subiektywnego odczucia czasu, który - choć jest traktowany przez dojrzewających nastolatków jako wyjątkowy - stanowi doznanie zaskakująco uniwersalne, będące $\mathrm{w}$ relacji $\mathrm{z}$ czasem mitycznym. W obu przypadkach doświadczenie tak podróży, jak i temporalnego zawieszenia umiejscowione jest na tle przyrody, która często nabiera symbolicznych, a wręcz psychoanalitycznych znaczeń. Autorka w swym zamyśle, który przedstawia dojrzewanie jako okres niemal sakralny, jest niezwykle konsekwentna - niweluje mniej lub bardziej oczywiste wątki socjologiczne (jak chociażby temat millenialsów czy wcześniejszych generacji X i Y, ale także istotne publikacje z ostatnich lat; Blumenkrantz, 2016) czy kulturowe (jedynie wzmiankuje o tzw. youth culture). Jednocześnie na marginesie pozostawia kwestie filmowe, nie zagłębiając się w gatunkowe rozważania, przez co ostatecznie po lekturze książki trudno wyznaczyć granice poetyki coming of age.

Swoją refleksję Kostyra (2019) rozpoczyna od zauważenia filmoznawczego lekceważenia dla tego „młodzieżowego” gatunku i jego rzekomo modelowej grupy odbiorczej: „[...] niewiele znajdzie się na usprawiedliwienie "filmu dla młodzieży«, który, bezpardonowo komunikując przeznaczenie filmu konkretnej grupie widzów, zawłaszcza gusta młodego pokolenia oraz ogranicza docelową widownię do tej, która wiekowo odpowiada protagonistom filmowym" (s. 9). Nieprecyzyjnie pokazuje jednak relacje między filmami o dojrzewaniu a chociażby high school movies, przez co można się zastanawiać, czy w ogóle mamy do czynienia z gatunkiem filmowym, a nie chociażby schematem

\footnotetext{
z konfrontacyjną postawą wobec ZSRR (zamiast doktryny Détente), z rehabilitacją weteranów wojny w Wietnamie (zamiast czekającej ich w kraju pogardy i zapomnienia) oraz z restytucją kapitalistycznego liberalizmu (w miejsce podnoszonych w dobie dzieci-kwiatów żądań lewicy). W sposobie sprawowania władzy wzorem dla Reagana był Dwight Eisenhower, a dla dekady lat 80. odniesieniem stały się lata 50. XX wieku" (Syska, 2012, s. 16).
} 
fabularnym. Da się przecież wskazać przykłady umieszczenia narracji o dojrzewaniu w konwencji horroru, jak w Mięsie Julii Ducournau (2016), czy superbohaterskiej, by wymienić serial Netflixa To nie jest OK (Entwistle, Hall, 2020). Podobnie w podrozdziale $Z$ historii filmowego lata w bardzo powierzchowny sposób zostaje nakreślona historia - przyjmując nomenklaturę autorki - omawianego gatunku. Kostyra celnie wskazuje, że lata 50. są momentem wyłonienia się kategorii młodości, a niezwykle ciekawe jest dostrzeżenie synchronicznego pojawienia się koncepcji autora, która poskutkowała chociażby nowofalowymi arcydziełami o dojrzewających bohaterach. Jednak w tekście nie dochodzi do sprecyzowania kontekstów kulturowych i choć wspomniane zostają filmy ze Szwecji czy Francji, to kinematografia amerykańska pozostaje niewidzialną ramą odniesienia - przykładowo, opisując serferów z beach party films, można było z powodzeniem napisać o podobnych dziełach australijskich, których bynajmniej nie zaprzestano tworzyć wraz z rewolucją seksualną. Kolejne dekady ujęte zostały w dwóch silnie generalizujących zdaniach: „Początek lat siedemdziesiątych przynosi zatrzęsienie filmów coming of age. Tendencja zresztą nie słabnie i utrzymuje się w kinie najnowszym" (Kostyra, 2019, s. 83). Czytelnik nie poznaje przyczyn, diagnoz czy nawet tez; nie wie, czy to stała tendencja i czy różni się zależnie od kontekstu kulturowego.

Zdecydowanie lepiej wypada opis cech coming of age movies. Kostyra (2019) wskazuje na elementy fabularne wynikające $\mathrm{z}$ koncentracji na doświadczeniu protagonisty: inicjację, ale i demistyfikację, rytuały przejścia, nastrój nostalgii, jak również wynikającą z nich epizodyczną strukturę oraz quasi-impresjonistyczną estetykę, które mają na celu podążanie przede wszystkim za subiektywnymi przeżyciami, mniej zaś - za logiką przyczynowo-skutkową:

Opowieści o dorastaniu starają się dosięgnąć nastoletniego stanu ducha, w którym wyczulona wrażliwość odpowiada na każde najmniejsze poruszenie świata zewnętrznego, wzbierając wciąż nowym doznaniem. W takich chwilach upijania się młodością ma się wrażenie, że cały świat należy do nas, a my już zawsze będziemy tacy szczęśliwi, odważni, zakochani. Właśnie na bolesnym przeżywaniu chwili obecnej i żalu za tym czasem "prawdziwego istnienia” bazuje kino, portretujące młodzież żyjącą pełnią życia (s. 12).

Ta pełnia życia, intensywność i poszukiwanie przygód mienią się w wizji autorki wszystkimi kolorami i dźwiękami lata, coming of age wypełnia „kwitnąca zieloność" (s. 13), rezonująca z uczuciami bohatera (lub bohaterów w przypadku portretowania przez film grupy rówieśniczej) i wręcz prowokująca próby przyjaźni i pierwsze miłości. Autorka wskazuje wyjątki od tej reguły, podając 
przykłady filmów, których akcja ma miejsce w innych porach roku, jednak to nie czas akcji zdaje się problemem - całościowy zamysł publikacji budzi wątpliwości, których książka nie rozstrzyga do końca.

Po pierwsze, będą to granice gatunkowe. Dlaczego inicjacje na szkolnych korytarzach, domówkach czy w skateparkach są wykluczone z tej refleksji? Momentami ma się wrażenie, że autorka dokonuje nadinterpretacji, gdy wpisuje, przykładowo, tory kolejowe w ramę psychizowanej natury i wykorzystuje symboliczne skojarzenia bohaterek ze zwierzętami. Po drugie, przez uznanie natury za ramę zaprezentowane w Wiosennej bujności traw ujęcie wydaje się konserwatywne. Autorka jest świadoma, że jej perspektywa jest bliska optyce romantycznej, w której duch czy dusza połączone były z siłami tajemniczej natury, jednak sama świadomość tego faktu nie sprawia, że obrana metodologia zakorzenia się w zainteresowaniach współczesnej humanistyki. Zdanie: „Przyrodę będziemy rozpatrywać od strony konkretu i metafory, dosłowności i symbolu, a także estetycznej fasady i natury rzeczy" (Kostyra, 2019, s. 14) pokazuje nie tylko rozmiar kategorii przyrody, lecz także brak wyjścia w stronę nowych dyskursów, przede wszystkim posthumanistycznych i ekokrytycznych, w których brak rozróżnienia natury i przyrody; pisanie o „człowieczym” bohaterze (s. 13) czy metaforyzowanie nie-ludzkiego świata wydają się wątpliwą zasadą.

W publikacji przyroda cały czas jest traktowana jako wypadkowa wrażliwości postaci, a zatem funkcja człowieka. Przykładowo, opisując relacje człowieka z przyrodą w dokumencie Płynq tratwy, autorka polemizuje z opinią jednego z krytyków o harmonijnej współegzystencji - akcentuje, że praca drwali jest pokazem siły i bezduszności, jednak wpisuje to $\mathrm{w}$ archetypiczno-symboliczny kontekst mitów o dorosłości (Kostyra, 2019, s. 72), a przez to nie podważa antropocentrycznej perspektywy. Oczywiście trudno mieć o to pretensje do autorki, która wyraźnie obiera uniwersalizującą, opartą na mitach perspektywę (choć trzeba przyznać, że kluczowy w tym kontekście Roland Barthes, 1977/1999, cytowany jest tylko z etapu poststrukturalnego), co jednak z pewnością ogranicza potencjalną aplikowalność analiz i narzędzi zaprezentowanych w Wiosennej bujności traw. Kwestia narzędzi, a raczej ich nieprecyzyjnego określenia, również jest zresztą problematyczna - nie dotyczy to bowiem jedynie podstawowej kategorii filmów coming of age, ale też figury nostalgii czy melancholii, co jest szczególnie wyraźne w kontekście stosowania aparatu psychoanalitycznego i odwołań do prac Sigmunda Freuda. Silniejsza podbudowa teoretyczna wzmocniłaby z pewnością argumentację autorki. Tego zarzutu nie można odnieść do nawiązań do literatury pięknej. Kostyra z pasją przywołuje bowiem cytaty i literackie motywy, wspominając chociażby Arthura Rimbauda, Bolesława Prusa, Marka Twaina, Lorda Byrona i Stanisława 
Czycza. Te nawiązania niekoniecznie pełnią funkcję merytorycznego wzmocnienia, lecz zwiększają poetycki wymiar publikacji, w czym zresztą leży jej największa wartość.

Autorka, jak już pisałam, słusznie wskazuje lukę w filmoznawstwie, które niemal programowo nie interesuje się kinem coming of age:

Niedostatek literatury przedmiotu może być dla zainteresowanego tematem nieco frustrujący. Taka sytuacja ma też jednak swoje dobre strony, bo pozwala początkującemu badaczowi na pewną swobodę, pobudza inwencję i zachęca do zabawy z przedmiotem. Jeśli czytelnik natrafi $\mathrm{w}$ dalszej części tekstu na nieco zuchwałe czy autorytatywne stwierdzenia, to należy je zrzucić na karb wolności, jaką przyznaje piszącemu filmoznawstwo niezainteresowane gatunkiem. Kiedy droga jest pusta, można przecież śmiało iść środkiem jezdni (Kostyra, 2019, s. 9).

Powyższy cytat wskazuje jednak dobitnie, że Kostyra wprowadza do polskiego dyskursu na temat filmu coś więcej niż tylko treści merytoryczne - Wiosenna bujność traw to dla mnie przykład postulowanej przez Laurę U. Marks (2002) krytyki haptycznej, która szuka środków ekspresji do oddania doświadczenia cielesnego, jakim jest odbiór filmu. Czasami styl autorki ją ponosi - nadużywa ona zdrobnień i kolokwializmów, które wprowadzać mogą w konfuzję, sugerując ironiczne podejście („sympatyczne słoneczko” czy natura jako „obrazek w tle” - Kostyra, 2019, s. 13; „sympatyczne zwierzątka” - s. 110; bohaterka „sypia z posiwiałym typem z zagranicy" - s. 120), gubi precyzję opisu (w podrozdziale o Stań przy mnie zamiast oczywistego słowa "retrospekcja” autorka korzysta z niedookreślonej figury „konstrukcji w głąb” - s. 28, co jest po części wynikiem hermeneutycznej pułapki i pozostania w obranym wcześniej kluczu dotyczącym transformacyjnej podróży bohatera; z kolei analizując osobowość protagonisty Zepsutego owocu, podaje w przypisie Ruth Benedict, 1946/1999, jednak w tekście głównym tworzy wątpliwe nawiązanie do bajki o trzech świnkach - Kostyra, 2019, s. 131), a także nie zawsze pogłębia własne diagnozy (jak w przypadku Królów życia, gdzie wskazuje przykładowe inspiracje, ale nie wyciąga z nich wniosków, pisząc: „Vogt-Roberts tworzy teledysk z młodzieńczych nastrojów cudownego życia, w którym upijanie się powietrzem odbywa się za namową natury" - s. 44). Usterki te uchylają się jednak przed dużą wrażliwością językową oraz pomysłowością literacką autorki, zresztą dwukrotnie wyróżnionej w Konkursie im. Krzysztofa Mętraka dla krytyków i krytyczek filmowych. Chciałabym podać kilka przykładowych fragmentów:

[O Zapamiętajmy to lato:] Intensywna zieleń i odcienie perłowe filmowane w miękkim świetle, to kolory lata ze wspomnień. Słońce nie razi już nieprzyjemnie 
swym silnym blaskiem, powleczone jest czułością spojrzenia z oddali, ciągle jednak przez wybijającą się zieloność ucieka bladej niepamięci (s. 88).

[O Wycieczce na wieś:] Dorastająca córka sklepikarza jest jak sama natura w mieszczańskich wyobrażeniach - słodka, swobodna, rozczulająca. I na odwrót, wspaniałość letniego dnia, dorodność przyrody wyobrażają w reifikacji dziewczęce pokwitanie. A wszystko niezwykle wyraziście zatapia się w tej jednej gorącej niedzieli 1860 roku (s. 100).

Dla większości bohaterów lekcja wakacyjnej miłości wiązała się z żalem, upokorzeniem i agresją, choć przyznać trzeba, że wszystkie te przykrości równoważone były jednocześnie upojnym sensualizmem płynącym z filmowych obrazów zakwitłej natury. Jeśli się zatracić, to tylko w tak wysokich trawach albo chłodnym potoku, jeśli za czymś tęsknić, to niech to marzenie ma przynajmniej piękną oprawę graficzną [...]. W tym cudzie rozgorączkowanej natury serce boli piekielnie (s. 151).

Te przykłady pokazują poetycką zmysłowość stylu Kostyry - autorka zaciera granice naukowego dystansu, wychodząc z całą otwartością w stronę młodości, której istotę stara się oddać w jej emocjonalnym poruszeniu. Zanurza się z lubością w intensywnych przeżyciach i czyni gest emocjonalnego przekroczenia, tak rzadkiego, paradoksalnie, szczególnie wśród młodych badaczy i badaczek. Pisze o filmach, które nie tylko opowiadają o głębokich doświadczeniach okresu dojrzewania, lecz także budzą zaangażowanie.

Początkowe wyznanie, że autorka obejrzała kilkaset dzieł coming of age, nie brzmi jak buta czy czcze przechwałki, lecz świadectwo miłości do tych filmów i do ich bohaterów. Tak jak oni swe „pierwsze razy” przeżywali bez dystansu i ironii, tak też o nich udaje się Kostyrze (2019) napisać w Wiosennej bujności traw. Intensywny sensualizm (który niekoniecznie współgra dobrze z tradycyjną psychoanalizą czy strukturalistycznym ujęciem mitu) i próbę oddania odczuwanej cieleśnie wzniosłości widać także w dobieranych kadrach ilustrujących rozważania, zwłaszcza w ujęciach z Zakazanego owocu, które wyselekcjonowane zostały z uwagi na doznania taktylne, jakie przedstawiają (a może i wywołują, odnosząc się do zmysłowej pamięci; s. 126). Przyjęcie takiego stylu w pracy badawczej wiąże się z odsłonięciem własnej wrażliwości, a i jest trudne do wyważenia. Autorka podołała jednak temu zadaniu, wzbogacając analizy filmów o dojrzewaniu o warstwę emocjonalną:

[...] kino coming of age z jednej strony obraca się wokół nastroju tęsknoty, żalu, nostalgii, które przyświecają pożegnaniu dzieciństwa i młodości, z drugiej zaś 
korzysta z radosnego oczekiwania, jakie młody bohater łączy ze swoją wymarzoną przyszłością. Rezygnacja i nadzieja nie są w tym przypadku przeciwstawnymi afektami, lecz raczej emocją o niejednorodnym zabarwieniu, słodko-gorzkim wspomnieniem czy samą młodością, w której mieści się tyleż rozpaczy, co afirmacji życia (s. 11).

Drobny zarzut w tym kontekście można odnieść do użycia pluralis modestiae, czyli wynikającego czy to z obiektywizacji, czy skromności zastosowania liczby mnogiej, zgodnego zresztą z manierą akademicką, nakazującą ukrywać się badaczowi czy badaczce. Gdy (inter)subektywizm staje się deklaracją książki, „ja” autorskie powinno odważnie podpisywać świadectwo własnych doświadczeń.

Taka perspektywa niweluje większość z wcześniejszych uwag, jako że kwestie precyzji można usprawiedliwić propozycją alternatywnego ujęcia, które - w czym leży jego duża wartość - jest w stanie zachęcić do lektury nie tylko badaczy, lecz także miłośników narracji coming of age. Na stronach Wiosennej bujności traw odzwierciedlone zostają zmysłowość opisu i kinofilska pasja. Jest jednak zarzut, do którego chciałabym wrócić: konserwatyzm. Nie mam tym razem na myśli korzystania z (do pewnego stopnia) przestarzałych narzędzi badawczych, lecz sposób ujęcia analizowanych filmów, szczególnie w kontekście ,ja” autorskiego, które jest „ja” sfeminizowanym. Kostyra (2019) wielokrotnie przyznaje, że filmy o dojrzewaniu to „raj chłopactwa” (s. 149), ponieważ dziewczęce inicjacje to przygody skrojone pod przydomowe ogródki i zorganizowane pikniki:

Powieść inicjacyjna czy film coming of age jawią się w tym przypadku jako lustro odbijające stan rzeczy zawarty w badaniach antropologicznych. Wszak w większej części świata kobiece rite of passage opatrzone są rangą mniej istotną od męskich inicjacji [...]. Kultura popularna przechwytuje te tendencje, skazując młode bohaterki na dojrzewanie jakby mimochodem, gdzieś nieopodal domu, bez sztafażu przyrody nieokiełznanej. Popkultra hołduje tym samym patriarchalnemu podziałowi, w myśl którego miejsce kobiet jest przypisane do przestrzeni domowych, podczas gdy mężczyzna - myśliwy, wojownik, rycerz, kupiec, podróżnik, eksplorator - nabywa doświadczenie, zdobywa „męskość” na zewnątrz, w świecie pełnym przygód i niebezpieczeństw (s. 48).

Badaczka jednak nie wyciąga z tej tezy dalszych wniosków. Opisuje mit dominującej ideologii, jednak akceptuje go i nie poddaje dekonstrukcji, podążając za męską nostalgią. Dziewczętom w książce poświęcone są dwa studia przypadku: Walkabout oraz Wycieczka na wieś; grupy chłopięce są zastanawiająco zunifikowane, ewentualnie poddane typizacji - jak w przypadku Stań przy mnie, 
gdzie zaznaczona zostaje obecność klasowych podziałów (klasistowsko zresztą akcentowanych w wywodzie: „Chris - najbardziej dojrzały z całej paczki - pochodzi ze zdegenerowanego lumpenproletariatu”; s. 30), nie ma w nich miejsca na zróżnicowanie etniczne czy seksualne, co kłóci się z najgłośniejszymi produkcjami inicjacyjnymi ostatnich lat, jak chociażby queerowymi czy nawet intersekcjonistycznymi filmami Życie Adeli - rozdział 1 i 2 (Kechiche, 2013), Moonlight (Jenkins, 2016) czy Twój Simon (Berlanti, 2018); więcej pisze o tym Magdalena Urbańska (2018).

Z Wiosennej bujności traw wyłania się tymczasem wizja niczym z sitcomu Przyjaciele (Crane, Kauffman, 1994-2004), który nie wytrzymał próby czasu, zderzając się ze współczesną świadomością i wrażliwością. Dobrym przykładem jest przywołany Walkabout. Autorka książki pisze o dziewczyńskim doświadczaniu natury ogólnikowo, bez exemplów - bohaterka filmu Roega (w tej roli Jenny Agutter) przekonuje się o słabości swojej wiedzy i przekonań o świecie w konfrontacji z przyrodą (co porównane zostaje zresztą w nie do końca zrozumiały sposób do rytuałów tubylczych, sugerując utożsamienie przyrody z Aborygenami - jako Innymi w Australii), za to jej brat (Luc Roeg) jest interpretowany jako romantyczne dziecię, które nie zatraciło jeszcze intuicji (Kostyra, 2019, s. 53). Z jednej strony badaczka momentami niezwykle celnie wskazuje zachodnie klisze, np. pisząc: „Jedynie intuicyjnie można domyślać się siatki percepcyjnej, w jaką Aborygen wpisuje napotkanych towarzyszy swojego walkabout. Sami arbitralnie wpisujemy go, prowadzeni konwencją, w rolę męskiego obrońcy rodziny, który odpowiada za bezpieczeństwo, zdobycie pokarmu i przekazanie odpowiednich wzorców synowi” (s. 57). Z drugiej zaś strony - nie dostrzega, że jej aparat psychoanalityczny sam je wzmacnia, przykładowo wtedy, gdy usilnie posługuje się figurą ojca, którą to rolę przejmuje po zmarłym rodzicu (John Meillon) najpierw Aborygen (David Gulpilil), a potem mąż bohaterki (John Illingsworth; s. 64). Dyskurs prowadzony przez autorkę wzmacnia tym samym seksistowską optykę w niektórych $\mathrm{z}$ opisywanych filmów. Podobnie dzieje się w podrozdziałach poświęconych Dancingowi w kwaterze Hitlera oraz Zepsutemu owocowi, które pokazują doświadczenia męskiego protagonisty w relacji z uwodzicielską partnerką. Opisy bohaterek kobiecych nie wydostają się poza seksistowski dualizm i esencjonalistyczne stereotypy: „To kobieta jest tą, która wkłada rękę w mrowisko, pozwala obleźć się robakom, nie fałszuje życia, to znaczy: nie wstydzi się pożądania seksualnego, ciekawi ją śmierć. Kobieta pod tym względem jest powiernicą tajemnicy życia i śmierci, jest samą naturą" (s. 115). W tę samą stronę podąża gęsta interpretacja symboliczna związana z kobiecością, światłem i wodą. Autorka korzysta z archetypów bez zwrócenia uwagi na ich patriarchalny charakter, a przez to wręcz go 
konstytuuje. W zakończeniu książki pada zdanie, że coming of age, jak każdy gatunek filmowy, ma mityczny wymiar: „Jednym $\mathrm{z}$ aspektów pielęgnacji mitu, za jakie odpowiedzialne są historie o dojrzewaniu, będzie więc gloryfikacja młodości, kokietowanie przyszłych inicjantów niezwykłością stanu przejściowego, tak by ci bez żalu wyrzekli się dzieciństwa" (s. 153). Autorka dostrzega wyraźnie ten konserwatyzm, więc szkoda, że nie wykorzystuje tego w bardziej krytyczny sposób.

Na początku wywodu Kostyra (2019, s. 7-9) wspomina o podrzędnym miejscu kina coming of age w oczach krytyków i filmoznawców, a często także filmowców, którzy decydują się swoje dotychczasowe doświadczenia wysublimować w debiucie, by następnie poświęcić się "dojrzalszym” tematom. W innym miejscu (s. 16) pisze o tym, że „pierwsze razy” protagonistów opisywanych przez nią dzieł są zarazem „ostatnimi razami”, momentem inicjacji i pożegnania. Mimo paru zastrzeżeń liczę na to, że naukowy subiektywizm i skupienie na emocjach oraz doznaniach nie są jedynie wynikiem młodego wieku „oszołomionej zielenią" badaczki.

\section{Bibliografia}

Barański, A. (reż.). (1991). Nad rzeką, której nie ma [film]. Telewizja Polska, Studio Filmowe Oko.

Barthes, R. (1999). Fragmenty dyskursu miłosnego (M. Bieńczyk, tłum.). Wydawnictwo KR.

Batory, J. (reż.). (1972). Dancing w kwaterze Hitlera [film]. Zespół Filmowy Syrena.

Benedict, R. (1999). Chryzantema i miecz. Wzory kultury japońskiej (E. Klekot, tłum.). PIW. (wyd. oryg. 1946).

Berlanti, G. (reż.). (2018). Love, Simon [Twój Simon] [film]. $20^{\text {th }}$ Century Fox.

Blumenkrantz, D. G. (2016). Coming of age the rite way: Youth and community development through rites of passage. Oxford University Press.

Burnham, B. (reż.). (2018). Eighth grade [Ósma klasa] [film]. A24.

Clowes, D. (1997). Ghost world. Fantagraphics.

Crane, D., Kauffman, M. (prod. wyk.). (1994-2004). Friends [Przyjaciele] [serial telewizyjny]. NBC.

Ducournau, J. (reż.). (2016). Grave [Mięso] [film]. Wild Bunch.

Eliade, M. (1997). Inicjacja, obrzędy, stowarzyszenia tajemne (K. Kocjan, tłum.). Znak. (wyd. oryg. 1959).

Entwistle, J., Hall, C. (prod. wyk.). (2020). I am not okay with this [To nie jest OK] [serial telewizyjny]. Netflix. 
Jenkins, B. (reż.). (2016). Moonlight [film]. A24.

Kechiche, A. (reż.). (2013). La vie d'Adèle: Chapitres 1 et 2 [Życie Adeli - rozdział 1 i 2] [film]. Wild Bunch.

Marks, L. U. (2002). Touch: Sensuous theory and multisensory media. University of Minnesota Press.

Nakahira, K. (reż.). (1956). Kurutta kajitsu [Zepsuty owoc] [film]. Nikkatsu.

Reiner, R. (reż.). (1986). Stand by me [Stań przy mnie] [film]. Columbia Pictures.

Renoir, J. (reż.). (1946). Partie de campagne [Wycieczka na wieś] [film]. Panthéon Production.

Roeg, N. (reż.). (1971). Walkabout [film]. $20^{\text {th }}$ Century Fox.

Shults, T. E. (reż.). (2019). Waves [Fale] [film]. A24.

Sołowjow, S. (reż.). (1975). Sto dnej posle detstva [Zapamiętajmy to lato] [film]. Mosfilm.

Syska, R. (2012). Reaganomatoretro, czyli czekając na herosa. Ekrany, 5(9), 15-19.

Ślesicki, W. (reż.). (1962). Płyna tratwy [film]. Wytwórnia Filmów Dokumentalnych.

Urbańska, M. (2018). Coming (out)-of-age. Wątki LGBT w amerykańskim kinie inicjacyjnym. Fragile, 4(42), 98-102.

van Gennep, A. (2006). Obrzędy przejścia. Systematyczne studium ceremonii (B. Biały, tłum.). PIW. (wyd. oryg. 1909).

Vogt-Roberts, J. (reż.). (2013). The kings of summer [Królowie lata] [film]. CBS Films. Zwigoff, T. (reż.). (2001). Ghost world [film]. United Artists. 